\title{
A via eXtralógica da PeSQUisa Pela VERDADE NOS DIÁLOGOS PLATÔNICOS
}

\author{
AN EXTRA LOGIC ROUTE FOR THE SEARCH OF TRUTH IN THE PLATONIC DIALOGUES \\ JACIR SILVIO SANSON JUNIOR* \\ Universidade Federal do Espírito Santo (UFES), Brasil. jasisaju@hotmail.com
}

Recibido ee 24 de MARZo de 2015, AProbado el 29 de MAYo de 2015

\begin{abstract}
Resumo
No artigo nos damos à tarefa de mostrar e demarcar a presença de uma via extralógica nos diálogos socráticos. É frequente no texto platônico a recorrência a essa via, sendo de fato uma dimensão que se soma ao percurso lógico-racional de uma conversação filosófica, tal como Sócrates tipicamente a empreendia conforme seu método, a maiêutica. O modo como realizamos isso foi o de percorrer algumas obras, principalmente Êtifron e Hipias menor, Lísis e O Banquete, de forma a ressaltar a atuação de elementos humano-afetivos sobre o discurso, que ora incitam ora desfavorecem o diálogo. Essa via aporta então pela perspicácia de abordar, simultaneamente ao desenrolar da pesquisa filosófica pela verdade, a influência de aspectos emocionais, psicológicos, morais e até institucionais. Concluímos que a via extralógica se registra textualmente, e recebe de Platão um reconhecimento equitativo ao plano discursivo dos argumentos, sendo, portanto igualmente valorizada na busca pela verdade. Trata-se de uma via mais sutil, eminentemente filosófica em suas raízes, e que se constitui ao longo da articulação metodológica.
\end{abstract}

\section{Palavras-chave}

Diálogos platônicos, dialética, maiêutica, verdade.

\section{Abstract}

This paper aims at showing and marking the presence of an extra logic route in the Socratic dialogues. In the Platonic text the recurrence of this pathway is frequent. It is indeed a dimension that adds to the logical-rational way of a philosophical conversation, such as Socrates typically undertook it according to his method, the maieutic. We accomplished this by going over some works, especially Euthyphro and Hippias minor, Lysis and The Banquet in order to emphasize the role of humanaffective elements on the discourse, which sometimes incite and other times harm the dialogue. This way contributes by the perspicacity of addressing, simultaneously the unfolding of philosophical search for truth, the influence of emotional, psychological, moral and even institutional aspects. We conclude that an extra logic route is registered textually, and it receives equal recognition at the discursive level of the arguments. It is constituted during the course of the methodological articulation and it is eminently philosophical in its roots.

\section{KEY WORDS}

Platonic dialogues, dialectic, maieutics, truth.

\footnotetext{
* Gostaria agradecer à Bárbara Botter por todo auxílio e colaboração.

ORCID: http:/ / orcid.org/0000-0003-2895-5549
} 


\section{Introdução}

"E o que queremos, declaremo-lo de uma vez por todas, é a verdade" (Platão, Fédon 66b). Não precisamos nos interrogar pela amplitude do conceito para visualizarmos que ela, a verdade, estava sempre no horizonte das conversações de Sócrates. Consonante a essa alta estimativa, a referência à verdade não se prestava apenas a um valor objetivo - a verdade como alvo de conjecturas da reflexão filosófica-, vindo a exercer também uma função genitiva, a saber: enquanto aquilo que engendra uma discussão filosófica.

Isso nos parece nítido nesta resposta a Êutifron: "mas nada é para mim mais agradável do que uma coisa ser verdade" (Platão, Êutifron 14e-15a). Ela evita que se esmoreça, no debate, o rigor necessário para se conhecer a natureza da piedade. Além disso, mostrar-se sob o patrocínio da verdade, como pretende Calicles (Cf. Platão, Górgias 482e, 484c), e o faz o próprio Sócrates (Ibid. 486e, 495a) no Górgias, ajuda a apaziguar as tensões surgidas em torno das argumentações em curso. Na realidade, se Sócrates visa dizer aquilo que no diálogo se expõe como a melhor expressão da verdade (Ibid.507c-d), seu empenho não tem por finalidade a erudição, e sim uma alma limpa com a que se apresentará diante do juiz (Ibid. 526c-e).

Há uma passagem no Fédon cuja similaridade de elementos se enlaça bem coesamente com um trecho do Górgias. Neste diálogo, Sócrates lida com um opositor de desconfiável amizade, Calicles (Cf. Platão, Górgias 499c), tendo assim de acautelar-se junto ao caminho mais formal: "descobrir o que há de verdadeiro ou de falso na matéria debatida” (Ibid. 505e). Já naquele, está rodeado por íntimos e mais achegados ouvintes ( $C f$. Platão, Fédon 86d-e), a ponto de não apelar ao dado da verdade, mas valer-se de outros arranjos, como "foi a maneira delicada, cordial e deferente com o que acolheu as objeções dos moços; [...] de fugitivos e derrotados, fez-nos voltar e concitou-nos a segui-lo, para considerarmos juntos o argumento" (Platão, Fedón 89a).

Na Apologia de Sócrates, também podemos notar como estes dois vetores, o intelectual e o passional, continuamente se intercruzam ao plano argumentativo. Para provar sua inocência, Sócrates rejeita a intenção de convencer por belas palavras (Cf. Platão, Apologia 17a-b): não almeja lutar pela sua vida enquanto não se confirme não haver justiça e verdade nos termos da acusação. Sócrates abre mão do recurso retórico de 
"discursos aprimorados" e "frases bem arranjadas" (Cf. Platão, Apologia 17b-c), bem como dos lamentos e gemidos (Ibid. 38d-e). A dificuldade (Ibid. 25a-c) e as contradições (Ibid. 25e-26a, 27c-e) que impõe a Meleto saciariam as exigências no contexto de um tribunal; é porém saliente a real motivação daquele episódio: a "grande animosidade", "as calúnias e a inveja das gentes" (Ibid. 18a), contra o que Sócrates lança mão de seus próprios "atos" - ع $\rho \gamma \alpha$ (Ibid. 32a) - cujo relato também apontaria para a verdade (Ibid. 32b).

A respeito da busca pela verdade, seria abrupto e parcial seguir somente os passos do percurso racional empreendidos nos debates travados por Sócrates. Os Diálogos de Platão operam com um nível concomitante, a saber: enquanto um tema é perseguido, algo no humano também vai sendo tocado, sutilmente. Isso integra o método socrático, como observa Azevedo (2012):

é no convívio espontâneo com os conhecidos (ou mesmo desconhecidos) que se cruzam diariamente no seu caminho que Sócrates testa a aquisição possível da sabedoria humana, a pesquisa dos valores pelos quais tanto a sociedade como o indivíduo devem reger-se. (60)

Há autores que já fizeram a experiência de acercarem-se ao dado filosófico ligado mais à vida que à pura especulação. Casertano (2008) falou da relação entre afetividade e racionalidade em Platão, visando espairecer um ambiente em que a verdade estivesse inserida entre a lógica e o páthos, e não exclusivamente no logos. É inseparável a ligação entre o discurso e o mundo dos afetos: a alma não conseguirá prestarse às altas formulações conceituais do pensamento se estiver doente e padecer da desarmonia dos desejos ${ }^{1}$.

Nessa mesma linha, gostaríamos de pontuar alguns elementos que formam uma compreensão mais dilatada do pensamento socrático, que teve por habilidade mover-se não apenas no terreno da articulação racional de termos, como na emergência de aspectos extralógicos

\footnotetext{
${ }_{1}^{1}$ Algumas referências indicadas pelo autor corroboram seu parecer: Leg. IX, 571b-572b; Soph. 227e-230d; Phil. 33d. Para o autor, também "o IX livro da República esboça o movimento agitado que está no âmago mais profundo, escondido e removido de cada homem. Platão [...] não está a falar só do tirano como figura política letal para cada constituição das cidades, mas está a construir também uma metáfora que vale para todos os homens, porque em cada ser humano está contida a possibilidade de tornar-se um tirano no interior da própria vida e, por conseguinte, de ser, dialeticamente, não mais tirano mas escravo de uma das tiranias mais violentas: a dos apetites tremendos e selvagens" (Casertano 6-7).
} 
presentes na rota de uma conversação filosófica. Tais elementos põem a girar a pesquisa pela verdade, e se conjugam ativamente, quando certo diálogo investe em um determinado tema: não são um adereço decorativo, pois se constituem como condições da verdade, embora numa via extralógica.

Se reescrevêssemos vários dos escritos de Platão considerando estritamente a articulação lógica dos termos, não saborearíamos da trama inerente ao gênero literário escolhido. Nas palavras de Victor Goldschmidt (2002): "longe de ser uma descrição dogmática, o diálogo é a ilustração viva de um método que investiga e que, com frequência, se investiga" (3).

Maria Helena da Rocha Pereira (2001) percebe que, relativo a Platão, esse mesmo gênero comporta peculiaridades: o acento mais dramaticamente expresso na forma de diálogo narrado no Górgias, Mênon ou Fedro não reproduz exatamente o processo adotado no Protágoras, Cármides e Lisis, em que Sócrates parece falar para um auditório anônimo; e as formas narrativas no Eutidemo, Fédon, Banquete e Parmênides não excluiriam de todo a Apologia de Sócrates, por cujo teor de apresentação encaixar-se-ia como monólogo (V-VII).

Em todo caso, um diálogo se embebe de um vigor interpelativo que encharca a trama de tantos outros nutrientes igualmente necessários quando na referência à verdade. Se a filosofia é o amor pela sabedoria ${ }^{2}$, diríamos: primeiro vem o amor, depois a sabedoria.

Debateremos essa questão no ensejo de mostrar seu relevo em alguns diálogos socráticos. Nas obras aqui trabalhadas destacamos a real pertinência de elementos extralógicos no desenrolar das conversações filosóficas. Eles participam constitutivamente do diálogo de Sócrates, sendo-lhe uma dimensão integrante.

\section{Êutifron e Hípias menor: retroagindo à ética}

Um atributo geralmente associado ao nome de Sócrates em História da Filosofia resgata o percurso de uma lógica radicada na gramática, incisivamente detida no significado rigoroso não somente de uma palavra, mas principalmente daquilo que emerge da relação semântica entre os termos.

${ }^{2}$ Para mais informações consulte: Lísis 216d-e, 218a-b; O Banquete 204a-b. 
Os exemplos são vastos. Por isso tomamos quase aleatoriamente estas interpolações no Êutifron: "então, a piedade é amada pelos deuses, porque é piedade, ou é piedade, porque é amada pelos deuses?" (Platão, Êutifron 10a); “[...] toda a justiça é piedade? Ou a piedade é toda a justiça e a justiça não é toda a piedade, mas alguma dela é piedade e outra não?" (Ibid. 12a).

O Êutifron parece a Santos (1983) um típico diálogo socrático, pois está estruturado às voltas com a pergunta "O que é?". A simplicidade dessa indagação é a causadora das grandes ambiguidades que Sócrates vai dissolvendo por meio de sua técnica refutativa: o elenchos. No modo de Sócrates conduzir os rumos (epagogê) da conversa, há sim uma face destrutiva, pois o respondente "é confrontado com duas declarações contraditórias a que teve de anuir" (18), emergindo daí uma aporia. Contudo há também um intento construtivo, pois "cabe às induções socráticas a função de incluir informação nova, agregada por meio de exemplos aceites por ambas as partes" (18).

As definições de piedade, no $\hat{E} u$ tifron, são trabalhadas sem se chegar a uma finalização ( $C f$. Platão, Êutifron 15c). Mas isso não significou que os esforços pela apreensão de um conceito tenham sido em vão. Não se deve medir o êxito do diálogo somente pelo saldo de conhecimento que se seguiu às interlocuções. As interrogações de Sócrates deixaram uma abertura na discussão, como se estivesse a abastecer o motor para ser retomada em outro momento e local oportunos (Ibid. 15d-e).

Uma prova disso está no exame de Humberto Petrelli (2011): se Platão não forjou um conceito rigoroso, esboçou, no entanto a busca de um discurso religioso mais racional e orientado pela natureza, em que o piedoso (hosios) não seria mais a mera imitação das ações dos deuses (Cf. Platão, Êutifron 5e-6a), mas passaria pelo crivo da reflexão sobre o justo e o injusto (Ibid. 14a).

Conforme esse comentário, se por um lado uma definição não é alcançada e nem fixada com pretensão de perenidade, como se houvesse encontrado seu encaixe numa Forma, por outro, o diálogo afirmativamente galga uma plataforma para se repensar a religião, o discurso religioso e a relação entre homens e deuses. É um diálogo discursivamente forte, capaz de movimentar estruturas de enrijecimento institucionais. $\mathrm{O}$ diálogo é discursivamente forte porque torna 'dialogáveis' questões que, não entrando no discurso, permaneceriam irrefletidas. 
Esse foco de análise nos permite olhar para dois semelhantes trechos do mesmo Êutifron e então ajuntarmos duas considerações. No primeiro, Êtifron acusa Sócrates de fazer andar as palavras em torno de si próprias (Cf. Platão, Êutifron 11c-e), instalando incertezas no mínimo inconvenientes para um espírito ávido pelo saber. No segundo, o dado se inverte, sendo Sócrates quem mais convincentemente identifica em Êtifron os traços de um Dédalo (Ibid. 15b-c).

Em nota, o comentário de Santos assinala uma percepção em vista do horizonte lógico-discursivo do texto em tela:

a graça de Sócrates é justificada pela sua habilidade em fazer
mover os logoi. Do mesmo modo, o escultor Dédalo, a quem
eram atribuídas as primeiras estátuas que infringiam a lei da
frontalidade, parecia por em movimento as suas obras. (47)

Se tripudiar com as palavras recebe um sentido negativo, o próprio Sócrates reestabelece o polo de positividade, ao custo de expor, mais uma vez, sua própria ignorância (Cf. Platão, Êutifron 11d).

É substancioso à compreensão dessas linhas o fato comparativo entre a presunção de Êutifron, que se tinha por grande conhecedor do divino (Ibid. e-5a; 6c), e as admissões de Sócrates, esperançosas ao início (Ibid. 5b-c, 6c-d), frustradas ao final (Ibid. 15e). Esses fatores não ficam distantes de uma leitura moral considerando a simplicidade deste e a arrogância daquele. Está em causa não apenas a questão intelectual de se levantar problemas insuspeitos ${ }^{3}$, mas também a questão humana de se lidar com certas qualidades mais ou menos favoráveis ao percurso filosófico. As estátuas movediças de Dédalo são uma metáfora não só para a insuficiência das definições propostas de piedade (Ibid. 15c), como daquilo que em termos de orgulho e humildade opera internamente aos debatedores.

Há de se pontuar o franco propósito de Sócrates em formar um vínculo ou uma espécie de contrato, base necessária para seus testes de hipóteses. “Como me pareces indolente ( $\tau \rho \nu \varphi \hat{\alpha} v)$, eu próprio me esforçarei em

\footnotetext{
${ }^{3}$ A estimativa em se buscar uma formulação rigorosa dos conceitos é uma visão que aparece com ressalvas nas palavras de José Ferrater Mora (apud Petrelli 265): “devido às suas constantes interrogações, Sócrates fazia surgir o que antes parecia não existir: um problema. E, através dessas interrogações, todo seu esforço se concentrou em descobrir problemas mais do que buscar soluções. O problema fazia desvanecer os falsos saberes, as ignorâncias encobertas, as satisfações inautênticas".
} 
conjunto contigo $(\sigma \nu \mu \pi \rho \circ \theta v \mu \eta \hat{\sigma o} \mu \alpha \imath)$ por mostrar como me hás-de ensinar acerca da piedade" (Platão, Êutifron 11e). Esses enlaces não possuem somente uma utilidade metodológica, pois instigam a fronteira do estritamente argumentativo, acenando para indisposições de cunho mais íntimo e pessoal, da ordem das paixões ${ }^{4}$.

No Hípias menor, essa importância é colorida de forte tonalidade especialmente em 373b, quando Sócrates é acusado de 'desonesto' (ä $\delta 1 \kappa o v)$. A irritação de Hípias, de força determinante para fazê-lo abandonar a discussão, contrasta enormemente com suas gentis promessas de solicitude (Cf. Platão, Hípias menor 363c-d, 364d). A interveniência de um Sócrates que, visivelmente, não se adequa aos padrões de público que Hípias teria em perspectiva (Ibid. 363d), tende a incomodá-lo de certo no que tange não ao conhecimento, mas à estima e si ${ }^{5}$.

O descompasso que a condução socrática acomete a Hípias ocorre depois de demonstrar que o veraz e o mentiroso podem ser não dois, mas o mesmo homem (Ibid. 367c-d, 369a-b). Isso não só impõe a Hípias uma contradição em sua leitura de Homero (Ibid. 364c, 365b), como o enquadra inadvertidamente no perfil de um mentiroso: considerado tão ilustre (Ibid. 364a-b) e imbatível em todas as artes (Ibid. 368b-e), considerando-se o mais hábil em aritmética (Ibid. 366d), perito em geometria (Ibid. 367d), excelente em astronomia (Ibid. 367e-368a), Hípias reúne em si as condições ideais do maior de todos os embusteiros; não está isento de ser um exímio loroteiro, pois o mais plausível seria tomálo efetivamente como um mendaz, a julgar pela ridicularização no tom de Sócrates (Ibid. 364b, 368c).

Mais uma vez, porém agora com Hípias, vemos a acuidade do diálogo platônico em manejar, pari passu ao desencadeamento de um assunto lógico, aquilo que opera na edificação ética do homem. É improvável que estas palavras de Sócrates não possam servir de admoestação moral com o mesmo tino da refutação lógica:

\footnotetext{
${ }^{4}$ Isso é indicado nas palavras de Victor Goldschmidt escolhidas por Petrelli: “acontece, por vezes, a Sócrates, propor uma tese ( $C f$. Filebo), mas que é apenas um ponto de partida; é bem necessário que a pesquisa tenha um ponto de apoio. Ora, a dialética é uma pesquisa em comum. Impossível discuti-la se um dos interlocutores pretende deter a verdade e recusa, de vez, ser refutado. Não se trata, pois, como nos concursos erísticos, de impor ao adversário, por todos os meios, uma tese pessoal, sob pena de 'quebrar a cara'. É preciso que os interlocutores liberem, em si, o princípio racional das servidões passionais, porque a razão adere à verdade, enquanto a paixão se atém à sua verdade" (267).

${ }^{5}$ Hípias é comparado ao lutador que, tão seguro das próprias forças, compete absolutamente certo da vitória (Cf. Platão, Hípias menor 364a).
} 
agora, como vês, ficou bem claro que a mesma pessoa é a um só tempo falsa e verdadeira, de forma que se Odisseu é falso, é também verdadeiro, e se Aquiles é verdadeiro, é também falso. Não diferem entre si, nem são opostos, porém iguais. (Platão, Hípias menor 369b)

Quem mais poderia ser essa "mesma pessoa" senão o próprio Hípias! Ao mesmo tempo em que, no plano lógico, os debatedores são confrontados com um novo saber, na dimensão extralógica, tanto Hípias como Sócrates se veem resistindo a aceitar para si mesmos o que a razão colocou como sendo o mais verdadeiro. A existência de uma dimensão extralógica, onde o humano é eticamente 'construído' paralelamente à exercitação do método, torna-se surpreendentemente palpável na interpelação final do Hípias menor ${ }^{6}$ que, resumidamente, move-se do problema teorético da mentira para a questão ética sobre o mentiroso.

Nossas considerações suplantam a visão que aborda de forma módica o conjunto dos diálogos aporéticos. Tidos como a primeira fase de Platão, neles se é fundamentalmente proposta uma definição de virtude; desse modo, segundo Pereira, "o Lísis falha em definir a amizade, o Cármides a temperança (sophrosyne), o Laques a coragem, o Êtifron a piedade" (XVIII-XIX). Nossa tese é de que esses Diálogos, na realidade, forjam uma estratégia filosófica de cuidar da formação do ser humano, desde o lugar onde se articulam e se solidarizam o lógico-racional e o extralógicoexistencial, o entremeio onde o discurso é rompido.

Tratemos uma vez mais desse assunto visitando agora os diálogos Lísis e $O$ Banquete.

\section{Lísis e $O$ Banquete: romper o discurso}

A título de exemplo, poderíamos olhar para uma célebre passagem do Fédon e decantar de suas páginas o que nelas se entreveem como uma teoria gnosiológica. As palavras de Sócrates a Símias, recordadas por Fédon, modulariam um dualismo metafísico e axiológico polarizando o corpo e seus caprichos, de um lado (Cf. Platão, Fédon 66b-c), e a Filosofia e o conhecimento exclusivamente científico, de outro (Ibid. 66d-e).

\footnotetext{
${ }^{6}$ Veja-se em 376b-c do Hípias menor como o testemunho literário fotografa o instante em que ambos os registros se 'descolam': Sócrates e Hípias admitem a verdade do raciocínio; mas algo neles brada a acolhê-lo para si mesmos. Isso é igualmente destacado em 513c no Górgias.
} 
Tal leitura é, porém demasiado parcial, se em linhas adiante quisermos ouvir um convite bem mais exigente: zelar pelo corpo acarretaria um engajamento multidisciplinar do filósofo que, para manter-se o mais livre possível da "insanidade do corpo" (Cf. Platão, Fédon 67a), acautelar-seia na prevenção dos receios, cupidez e imaginações, guerras, batalhas e dissensões, e de tudo o mais que lhe empecilhe à "caça da verdade" (Ibid. 66c).

O contato literário com as atuações de Sócrates nos escritos platônicos nos coloca diante de uma dialética não estritamente lógica, porque eivada de situações não necessariamente ligadas a proposições terminológicas ou judicativas. Essa dimensão compreende algo de uma sutileza antropológica e é por vezes tangenciada por estudos que visam precisar uma definição do conceito de philia na obra platônica.

A amizade está antes na face de um Lísis, que se enrubesce ao participar do desenvolvimento de raciocínios (Cf. Platão, Lísis 213d), do que no universo do discurso socrático. A melhor definição de amizade está, como o próprio Sócrates reconhece, no semblante avermelhadíssimo de Hipótales (Ibid. 204b-c): com receio de ser desagradável a Lísis, acomoda-se um pouco mais distante (Ibid. 207b), mas é o primeiro a se agraciar com as explanações do filósofo (Ibid. 222b).

Não seria tão caro à Filosofia de Platão a abstração, a análise, a compreensão, o rigor lógico e crítico do pensamento, se não houvesse uma mobilização da palavra para fora da linguagem ${ }^{7}$. Na primeira parte do Lísis, assistimos Sócrates formando uma recomendação prática e diligente para Hipótales, apresentando-o como um adiantado no amor (Cf. Platão, Lísis 204b), mas com problemas com seu amado (Ibid. 206bc). A plataforma estritamente teorética da concepção poética de amizade

\footnotetext{
${ }_{7}$ A amizade por Sócrates levaria Críton a burlar as leis ( $C f$. Platão, Críton 45a-b), cometendo assim injustiça (Ibid. 46b). Em contrapartida, é em nome da amizade que Sócrates dissuade Críton de salvá-lo (Ibid. 44e-45a). A chamada "prosopopeia das leis" (Ibid. 50a-54d) funcionaria como o emblema que reuniria para si essas contradições menores e, então, transpô-las, já numa ordem superior de coerência. Na realidade, o mútuo apreço que ambos se dedicam, a ponto de imaginarem-se um no lugar do outro, é o que orienta toda aquela seção (Ibid. 50a, 50c, 51c, 52a, 52d, 54d), tendo sido colocado por Platão bem ao início do diálogo: “Sócrates —Porque não me acordaste logo e ficaste sentado em silêncio? Críton- Por Zeus, Sócrates, nem eu quereria ficar acordado com esta dor" (Ibid. 43b). Se a presentificação das leis de Atenas vem caracterizada pela típica dialética de perguntas e respostas (Ibid. 50c-d), estruturando uma sequência de argumentos incontestáveis -o nascimento, a educação, a união matrimonial etc.—, em sua medula está motivações genuinamente afetivas: “ó Sócrates, grandes são para nós as provas de que nós e a cidade te agradamos. De outro modo, como é que, mais que todos os outros Atenienses, continuas a viver em casa nesta cidade, se não te agradássemos?" (Ibid. 52b).
} 
baseada na natureza (Cf. Platão, Lísis 214b-c) cede em vista de uma visão mais aberta para novas evidências (Ibid. 216c-d) e mais afim com um agir ético responsável e altruísta (Ibid. 214e, 220b).

A dialética entre amizade e 'desejo' -'غ $\pi \imath \theta v \mu$ ía (Ibid. 221d) - tem seus percalços no universo abstrato dos conceitos (Ibid. 220c-d), mas não se pode dirimir sua importância na atualidade do amor, isto é, na vida dos amantes (Ibid. 210b-e): ligado ao desejo, o amigo verdadeiro, antes manipulável em combinações ambíguas e absurdas (Ibid. 213ab), finalmente se estabelece como um genuíno e não fingido amante

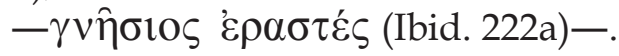

Um foco de análise para o Lísis consistiria em seguir os rastros das três teses refutadas por Platão sobre a amizade, como o faz Zoraida Feitosa (2013). Já na perspectiva extralógica, a obra não deveria ser vista como um mero debruçar sobre um tema, tão pouco como uma tentativa de delimitar filosoficamente um termo. A nosso ver, a aporia não é o símbolo de imaturidade ou fracasso para aquilo que se convencionou denominar "diálogos da juventude"; ao contrário, ela é um poderoso nexo de se vincular e não permitir desassociar, nos termos de Gabriel Rodrigues Rocha (2013), o "logos discursivo" do "logos vivo" (139-141). Por ser o Lísis um diálogo de primeira época, tende-se a pensar que lhe falta a maturidade necessária para levar adiante as discussões conceituais. Contudo a verdade talvez envolva não antes um conhecimento seguro e fixado doutrinalmente, mas a reconstrução do homem a fim de capacitá-lo a ela. A verdade está refletida nos traços de uma fineza, como declarado por Sócrates a Calicles: "estou convencido de que, encontrando-te, encontrei em tua pessoa semelhante jóia" (Platão, Górgias 486e), uma "alma de ouro" (Ibid. 486d). Essa tão alta consideração não estabelece um consensus omnium entre eles, mas abranda qualquer indisponibilidade de Calicles a fim de que, através de sua permanência e possíveis colocações, o diálogo ganhasse um andamento e, por que não, uma destinação.

Essa dimensão concomitante à logicidade do discurso se tornou eruptiva em Platão quando o assunto foi o amor. Em $O$ Banquete, as exposições ordenadas pelo simposiarca são interrompidas pelo frenesi de Alcibíades, explodindo com aquele espaço de ordenamento que sequer o vinho conseguiu desestabilizar (Cf. Platão, O Banquete 212cd, 214a). À tentativa de restaurar uma organização (Ibid. 222d-223a), uma súbita invasão de beberrões (Ibid. 223b) arruína toda chance de se retomar aos discursos. 
Alcibíades é convidado por Erixímaco a discursar (Cf. Platão, O Banquete $214 \mathrm{~b}-\mathrm{c})$, mas se deveria ter sido num tom eloquente e racional dirigido a Eros, partilhou de um amargo que confrontou o encômio proferido por Sócrates (Ibid. 212c). De fato, parece assombroso que o texto tenha reservado estas palavras àquele quem, no entender de Alcibíades, fez pouco caso do Amor: "essa a razão de eu afirmar que todo homem precisa honrar o Amor, [...] concitando os outros a fazerem o mesmo e louvando, agora e sempre, o poder e a coragem do Amor, dentro de minhas possibilidades" (Ibid. 212b).

José Cavalcante de Souza (1991) avalia que, quando Sócrates cede a palavra à sacerdotisa de Mantineia (Cf. Platão, O Banquete 201d), ocorre uma passagem do método dialético para a exposição alegórica, pois Sócrates não reproduz com Agatão o modo como Diotima fizera com ele próprio, em que ela discorria interrogando-o. A alegoria se apresenta, portanto quando não é Sócrates quem fala, mas Diotima, através dele. Há nisso um primeiro romper do discurso lógico: quando a palavra é cedida ao mito.

A nosso ver, o dizer de Sócrates é, na realidade, aquele que ecoa sob a elaboração de Alcibíades (Ibid. 214e-215a, 215d-e, 218c-d), queixoso e incontido por não ter recebido a atenção amorosa que pensava merecer (Ibid. 217a). Alcibíades reclama pela verdade (Ibid. 215a, 216a, 217b, $217 d, 218 c)$, mostrando que, se ele não conseguiu realizar-se em seus desejos (Ibid. 219d-e, 222b), foi o amor que pôs em operação a percepção daquela estátua interior (Ibid. 215b, 216d-e, 222a) responsável para que tal relacionamento não desvanecesse e constituísse, enfim, uma história (Ibid. 218d-219a).

Em vez da condecoração da Filosofia, que Jaeger (1979) vê presente na superioridade da participação de Sócrates ante os demais expositores do Sympósion ${ }^{8}$, assistimos ao sobressalto do regime dialético para o testemunho rasgado de Alcibíades. No ambiente de seu depoimento

\footnotetext{
${ }^{8}$ Para Jaeger, "Platão preferiu compor o Banquete na forma de uma série de discursos independentes uns dos outros, com a conseqüente renúncia a uma estrita aplicação do método dialético" (677). Congregando representantes da cultura grega, como o poeta trágico Ágaton e o comediógrafo Aristófanes, o banquete se desenrola, visivelmente, na direção do "primado da filosofia sobre a poesia" (Ibid. 673), tratando as intervenções pregressas "como socalcos que gradualmente vão subindo até [o de Diotima]" (Ibid. 676), e alcançando em Sócrates uma espécie de unidade espiritual: "Nenhum diálogo corresponde melhor que o Banquete a uma determinada situação espiritual e moral desta natureza; deve ser considerado apenas um coro de vozes reais da época, do qual se ergue no fim a de Sócrates, como voz dirigente e vitoriosa" (Ibid. 676).
} 
desesperado, a lógica socrática não se forma naquela circunscrição analítica das definições, mas ganha os traços de um estado bem mais desolador (Cf. Platão, O Banquete 217e-218b) ${ }^{9}$.

O elogio de Alcibíades a Sócrates contrasta com o elogio ao deus, que da boca de Agatão levantara estrondosos aplausos (Ibid. 198a). Também Sócrates recebeu felicitações após sua intervenção (Ibid. 212c); porém "quando Alcibíades acabou de falar, todos riram da sua franqueza, por parecer que ele ainda era apaixonado de Sócrates" (Ibid. 222c). Sua fala é decorada de censuras (Ibid. 222a), enquanto ainda vislumbre quaisquer traços de divindade (Ibid. 215b, 217a, 219c, 222a) naquele por quem deseja ser exclusivamente amado (Ibid. 222d). Se Alcibíades é intempestivamente afeiçoado aos raciocínios de Sócrates, é por algo mais que a lógica dos raciocínios (Ibid. 216c).

Alcibíades reconhece ser especialmente vulnerável às palavras de Sócrates (Ibid. 215e) ${ }^{10}$. Mas seu 'elogio' (Ibid. 217e, 222a, 215a) é expressão de uma realidade que, sem reverter-se em lógica, coexiste ao encadeamento dialogal das ideias. Em relação à verdade, a construção desse 'espaço' é tão necessária quanto o argumento racionalmente mais plausível.

Averiguamos então dois paralelos que tendem a produzir uma concordância entre Sócrates e Alcibíades. O mito do nascimento do demônio Eros (Ibid. 202e) se compactua aos primeiros passos da recordação dos ensinamentos de Diotima: assim como o Amor que, herdando os predicados de Poro e Penia (Ibid. 203b-c), encontra-se "sempre a meio caminho da sabedoria e da ignorância" (Ibid. 203e-204a), a "opinião verdadeira é qualquer coisa desse tipo, entre a compreensão e a ignorância" (Ibid. 202a). Na busca da verdade, a natureza do amor se alia à qualidade do discurso verdadeiro.

\footnotetext{
${ }^{9}$ Alcibíades compara sua dor ao envenenamento bem mais agudo ao das víboras ( $C f$. Platão, $O$ Banquete 217e-218b).

${ }^{10}$ Essa predisposição é oposta, especialmente, à de Calicles que, no Górgias, desdenha do pensamento de Sócrates, vendo-o como sutilezas tolas e palavrório sem valor (Cf. Platão, Górgias $486 \mathrm{c}, 489 \mathrm{~b}-\mathrm{c})$. De fato, Alcibíades se apaixona por algo infinitamente mais eloquente posto às escondidas nos exemplos de ferreiros e sapateiros que Sócrates costumeiramente evocava (Cf. Platão, O Banquete 221d-22a), e que Calicles, por sua vez, menospreza (Cf. Platão, Górgias 490c-491b, 497b). Distinto ao Alcibíades de O Banquete, o Calicles de Górgias não se encanta com Sócrates ou suas palavras. A ausência daquela empatia é testada como um risco ao diálogo que, para manter-se, precisaria do comprometimento estrito de um acordo: nesse caso, não apenas de responder ou perguntar (Cf. Platão, Górgias 490d, 497b), mas de ser honesto em dizer o que pensa, sem se acanhar (Ibid. 488d, 489c-d).
} 
No segundo paralelo, vemos que Alcibíades, durante toda sua participação, também se coloca em lugar intermediário, por assim dizer, entre Sócrates e Agatão (222e). Um circuito propício para o Amor é criado desde o momento em que Alcibíades é pelo enamoramento deslocado de sua autodeterminação - “o fato é que ele [Sócrates] me obriga a confessar que sou deficiente [' $\varepsilon v \delta \varepsilon \eta ́ c]$ " (Ibid. 216a) - e colocado nas condições da indigência que busca a riqueza (Ibid. 203c): no caso, os traços de divindade vislumbrados em Sócrates e seus discursos (Ibid. 215b, 217a, 222a).

Alcibíades não emite portanto um discurso qualquer, seja retórico, seja um convite à contemplação do Amor (Ibid. 210e-211a), mas uma opinião verdadeira desde a zona em que acontece, verdadeiramente, o amor. Em vez de discursar sobre o Amor, Alcibíades ama enquanto discursa.

A interferência de Alcibíades, como quem compareceu sem ser convidado, extrai das considerações de Sócrates um prelúdio e um embolismo que se conectam intrinsecamente à sabedoria dialética. Antes de Alcibíades arremeter-se a suas conclusões, não omite a réplica que delicadamente Sócrates aponta, sugerindo-lhe equívoco (Ibid. 218d-219a). Antes, contudo, de reclinar-se ao leito de Sócrates para falar, ouve:

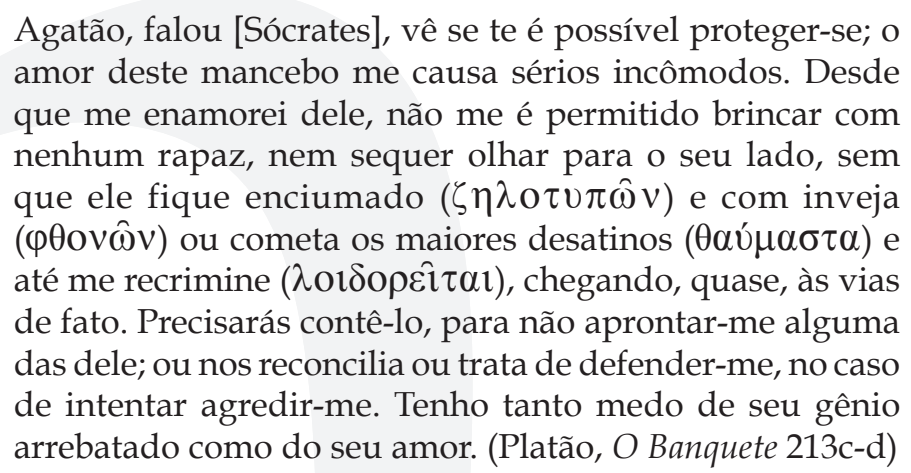

A combinação desses dois segmentos permite ratificar os pressupostos da via extralógica: mesmo se esquivando por duas vezes, Sócrates não desmente o relato de Alcibíades, cuja verdade é inatacável; trata, sim, de imiscuir-se de alguns infortúnios. O mito do nascimento de Eros traz consequências para a relação de amor, pois destaca um amante em condições completamente díspares à bela e excelsa figura do amado (Ibid. 204c): um quadro que também possui seus inconvenientes, mas 
abrange todo um horizonte não necessariamente identificado com o estrito rigor metódico.

A aceitação do argumento racionalmente mais plausível, e por isso verdadeiro, é uma função daquilo em que pomos afeição, daqueles para quem dirigimos nosso amor, numa palavra: o modo de vida pelo qual mais se anela ${ }^{11}$. Quando em questão está o modo de vida, para utilizarmos o texto de Rocha, da mesma forma que "existe em realidade a condição de modificar o pensamento, do simples para o complexo, do senso comum para o senso crítico" (Cf. Platão, O Banquete 143), há também "a possibilidade de renovar a conduta dos indivíduos, transformando-os tanto em relação à epistéme quanto em consonância a vida prática" (Ibid. 143)

\section{A via extralógica e o método maiêutico}

A relevância dos argumentos até aqui reunidos para mostrar a existência de uma dimensão extralógica em diálogos platônicos, além de nos solicitar uma nova postura intelectual ante esses escritos, também nos permite repensar como entendemos o método maiêutico.

Na primeira edição de sua obra Les dialogues de Platon, de 1947, para Victor Goldschmidt já se tornara “banal dizer que um diálogo de Platão não é construído como um manual de filosofia" (2), pois havia um lugarcomum onde se assentava a compreensão dos diálogos como "dramas filosóficos".

Contudo essa admiração pelos "elementos literários da obra platônica [...], os lances de teatro artisticamente dispostos, a diversidade dos episódios harmoniosamente distribuídos" (Ibid. 2), enfim, tudo o que compõe o "elemento dramático" poderia vir a descompensar a relevância do "elemento filosófico" que, para Goldschmidt, continuava sendo preponderante: "não parece [...] que a composição de um diálogo possa ser plenamente esclarecida pelas luzes das belas-artes" (2). E discernia

\footnotetext{
${ }^{11}$ É o que está francamente em jogo no encontro com Calicles, no Górgias, quando dando eco a 481d-482b, Sócrates diz: "o amor do demo, Calicles, que trazes na alma, é que trabalha contra mim" (Platão, Górgias 513c).

12 "Portanto, a todos àqueles que se dispunha a ouvir o discurso próprio da filosofia, possivelmente, este era o desejo de Sócrates e Platão, quiçá de todos os filósofos. Fundamentalmente dos filósofos da Antiguidade. É íntima, pois, a relação filosófica com a paideía grega, como o afirmara segundo se entende, corretamente, Werner Jaeger" (Rocha 143).
} 
uma notável diferença de finalidades: "o diálogo quer formar de preferência a informar" $(2-3)^{13}$.

Nossa pesquisa observou que, se na obra platônica o gênero dialógico sustenta toda uma cena artístico-teatral, isso não poderia se dar em prejuízo de um valor filosófico instalado precisamente no mesmo lugar, ao que chamamos via extralógica.

O que seria a via extralógica? Suscintamente, a percepção de elementos passionais, existenciais, psicológicos e institucionais, sediados no registro literário de tipo dialógico e que, na empreitada filosófica pela verdade, gozam de um reconhecimento equitativo ao discurso.

O que nos tornou possível levantar essa hipótese foi a natureza dos escritos platônicos e, acerca deles, intencionar uma leitura abaixo da superfície dessas “brilhantes peças dialéticas” (Santos 20). Queremos entender que, ao longo da arguição propriamente racional nos diálogos, também ocorre simultaneamente outra espécie de operação: assim como num patamar é preciso vencer certas dificuldades, também não se devem negligenciar os obstáculos próprios do outro plano. A característica do diálogo permite refazer o caminho de um argumento, demonstrando as resistências e os trejeitos pessoais dos interlocutores envolvidos como personagens.

O ‘dialógico' é composto por logos e o prefixo diá: remete a algo que está separado (diá) do discurso (logos), mas vindo a se tornar próximo por meio do diálogo. Platão o teria aplicado na relação entre oralidade e escrita, a fim de não perder as riquezas da palavra falada, que "sempre dispõe da possibilidade de abertura, de pergunta e de espaço para a contradição" (Rocha 139). Pudemos verificar o fato dessa correlação, tendo apresentado algumas evidências de como Platão intencionalmente abordava o "separado" enquanto tecia o discurso dialógico de Sócrates ${ }^{14}$.

\footnotetext{
13 "O manual do tipo corrente propõe-se a transmitir uma suma de conhecimentos, a instruir o leitor; o diálogo se fixa em um tema de estudo, não 'por interesse pelo problema dado, mas para torná-lo mais dialético em relação a todos os assuntos possíveis', ou ainda para torná-lo 'mais hábil'" (Goldschmidt 2).

14 "[...] a abstenção da escrita e a dedicação à palavra falada, ao diálogo vivo, significam que Sócrates foi um filósofo que agiu pela fala e por ela influenciou seus concidadãos - e se um indivíduo se define como político na medida em que age e influencia os demais por meio da palavra viva, em ato (isto é, a fala), Sócrates foi sem dúvida o mais público, o mais político, o mais cidadão de todos os filósofos" (Goto 113-4).
} 
Se apurarmos bem, notaremos no próprio termo maiêutica o prenúncio da via extralógica.

Segundo Petrelli, a apresentação tradicional do método socrático versa pela "condição para se produzir ou parir o verdadeiro conhecimento" (266). Das três etapas, refutação (elenkhos) da opinião (doxa), aporia (aporia) e maiêutica (maieutikê), as duas primeiras estariam nos diálogos da juventude intelectual; a maiêutica, apenas nos da maturidade doutrinais.

Mas essa concepção de "parto das ideias" ou "parto das almas" (Ibid. 266), a maiêutica como técnica utilizada para "desvelar todo um pseudo conhecimento" ou para "dissipar os conceitos mais firmes do adversário" com a "finalidade de fazer surgir um conceito novo", é demasiado metafórica e intelectualista. Não condiz com o 'Platão' com que tivemos contato. É de especial expressividade que no corpus platonicum haja essa abundância de traços extralógicos. Abre-se uma perspectiva de profundidade que se realiza em função da pertinência de múltiplos fatores humanos e passionais, afetivos ou temperamentais, imprescindíveis na pesquisa pela verdade.

Encontra-se no Teeteto de Platão (150c-151d) as principais asserções de Sócrates sobre sua arte. Ela é posta em analogia com a obstetrícia praticada pelas parteiras: se estas servem às mulheres e parem ao mundo um corpo, ele traz à conceição o fruto legítimo e verdadeiro da alma dos jovens belos e de boa origem.

Para Rocha, "a maiêutica como método de interrogação socrática, e, evidentemente, filosófica, desenvolve-se concomitantemente ao próprio desdobramento textual dos Diálogos, com os seus interlocutores" (141). Mas os obstáculos propriamente intelectuais não respondem unicamente pelas adversidades envolvidas na trajetória filosófica pela verdade. A excelência da aretê socrática não consiste em protagonizar um intuito pelo saber se, intimamente associado a isso, as personagens não são interpeladas a se temperarem na virtude. A fim de perfazer esse caminho, Sócrates não exprime pretensão de adquirir mais conhecimento das coisas, e sim mais liberdade de si mesmo ${ }^{15}$.

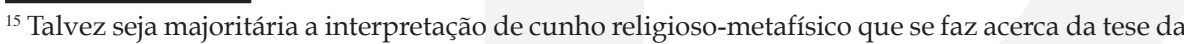
'revivescência' (Platão, Fédon 72a, 71c-72a) e da 'reminiscência' (Ibid. 74d, 75c-d). Isso não exclui a possibilidade de uma assimilação simbólica do Fédon, no caso de se representar um homem inteiramente livre para o conhecimento das coisas e desimpedido para adquirir sabedoria.
} 
O foco é que, tratando-se de uma arte relacionada à alma, a maiêutica torna melhores os cidadãos. Ela não se presta meramente à formação de um saber novo e especulativo: é, como arte, um partejar, tendo então de lidar com o visceral, íntimo e esplâncnico da alma.

É um forte indicativo que a investigação pela verdade, nos diálogos aqui mencionados, tenha o seu desfecho decidido não na coesão das ideias, mas na edificação de novos laços de solidariedade: não é só aquilo que persuade o pensamento, mas também tudo que sensibiliza e põe a mover certas disposições interiores da pessoa.

\section{Conclusões}

Nessa incursão aos diálogos Êutifron e Hipas menor, Lísis e O Banquete, notamos que a pesquisa pela verdade, tal como empenhada na dinâmica das conversações socráticas, articula-se com uma dimensão que não se pode identificar e tampouco reduzir à definição terminológica. Platão mostra que nem sempre o caminho pedagógico mais formal, aquele ligado à razão científica, é o mais apropriado à pergunta pela verdade.

Se aceitarmos como eloquentes os dados textuais apresentados, vemos que a insuficiência de argumentos para confirmar uma persuasão é suprida por elementos que não apenas aportam ao problema da piedade, da mentira, da amizade ou do amor, como ainda se insinuam acerca do que deixamos sugerido em notas sobre outras obras, como o Fédon, a Apologia, o Críton e o Górgias.

O acúmulo desses indícios resultou, por fim, em perceber no Teeteto a possibilidade de remeter a maiêutica a um novo quadro semântico, de grande sonoridade no horizonte de ensino e difusão da Filosofia.

Platão exibe uma habilidade extraordinária em mostrar a influência de tantos aspectos psicoafetivos que pululam no itinerário da indagação pela verdade. Incriminação, sentimento de inveja, o amor à discussão, amizade, boa estima e cordialidade, se estão aí, plantados nas páginas de estilo dialogal, é porque a vitalidade do ensino filosófico não consiste em ser um método tecnicamente infalível de verdade, pois sua perspectiva é a construção de um homem que se liberte de si mesmo para caminhar ao encontro dela. 
A genialidade de Platão em atravessar com perspicácia tantos aspectos de cunho existencial e emocional, inegavelmente úteis em qualquer senda educacional, convence-nos quanto à relevância da via extralógica na tradição filosófica platônica. Por conseguinte, uma dialética não é aquilo que se dinamiza com as proposições de um debate lógico, mas o que se acopla de extralógico ao se discutir um tema.

Em tudo isso está a verdade e o bem como perspectivas: não se atém à mera transmissão de conteúdos científicos, enquanto não se abarque também uma interpelação do humano em tantas outras dimensões que não apenas a teórico-racional.

\section{REFERÊNCIAS BIBLIOGRÁFICAS}

Azevedo, M.T. Platão: helenismo e diferença - raízes culturais e análise dos diálogos. São Paulo: Annablume Clássica, 2012. Impresso.

Casertano, G. "A verdade platônica entre lógica e páthos". Anais de Filosofia Clássica. 2008: 1-18. Web. 14 abr. 2014. <http://www.afc.ifcs. ufrj.br/>.

Feitosa, Z.M.L. "A influência da amizade nas Constituições políticas em Aristóteles". Prometeus. Jan.-Jun. 2013: 119-128. Web. 3 maio 2014. <http://seer.ufs.br/index.php/prometeus/issue/view/113/ showToc>.

Goldschmidt, V. Os Diálogos de Platão: estrutura e método dialético. São Paulo: Loyola, 2002. Impresso.

Goto, R. "O cidadão Sócrates e o filosofar numa democracia". ProPosições. Abr. 2010. Web. 17 jul. 2014. <http://www.scielo.br/scielo. php?script=sci_arttext\&pid=S0103-73072010000100008\&lng=pt\&nrm =iso>.

Jaeger, W. Paideia: a formação do homem grego. São Paulo: Martins Fontes, 1979. Impresso.

Pereira, M.H. "Introdução". Em Platão. A República. Lisboa: Fundação Calouste Gulbenkian, 2001. Impresso.

Petrelli, H.Z. "Eutífron e a discussão sobre a piedade". Kínesis. Jul. 2011: 263-281. Web. 26 mar. 2014. <http:/ / www.marilia.unesp.br/\#!/ revistaseletronicas/kinesis/edicoes/2011---volume-3-5/>. 
Platão. Diálogos: Protágoras, Górgias, O Banquete, Fedão. Belém: Universidade Federal do Pará, 1980. Impresso.

---. Êutifron, Apologia de Sócrates, Críton. Lisboa: Imprensa Nacional, 1983. Impresso.

---. Hípias menor. Web. 7 abr. 2014. <http:/ / www.cinfil.com.br/arquivos/ hipiasmenor.pdf>.

---. Lísis. Brasília: Editora Universidade de Brasília, 1995. Impresso.

---. Teeteto. Lisboa: Fundação Calouste Gulbenkian, 2010. Impresso.

Rocha, G.R. "Caminhos possíveis do Diálogo Lísis de Platão". Intuitio. Jun. 2013: 138-154. Web. 9 jun. 2014. <http:/ / revistaseletronicas.pucrs. br/ojs/index.php/intuitio/issue/view/691>.

Santos, J.T. “Introdução”. Em Platão. Êutifron, Apologia de Sócrates, Críton. Lisboa: Imprensa Nacional, 1983. Impresso.

Souza, J.C. “Texto, tradução e notas”. In J.A.M. Pessanha (org.). Platão. São Paulo: Nova Cultural, 1991. Impresso.

\section{Como citar:}

Sanson, J. "A via extralógica da pesquisa pela verdade nos diálogos platónicos". Discusiones Filosóficas. Ene.-Jun. 2015: 13-31. DOI: 10.17151/difil.2015.16.26.2. 